\title{
Mensurando Alteridades, Estabelecendo Direitos: Práticas e Saberes Governamentais na Criação de Fronteiras Étnicas*
}

\author{
João Pacheco de Oliveira
}

Professor titular do Museu Nacional, Universidade Federal do Rio de Janeiro. E-mail: jpo.antropologia@mn.ufrj.br.

\section{INTRODUÇÃO}

$\mathrm{E}$ ste artigo pretende focalizar a quantificação por meio de dois procedimentos nela contidos - a comparação, operação lógica que faz parte de um processo cognitivo, e a normatização, ato de ordenamento político camuflado em técnicas e rotinas administrativas. Quando um ator social pratica o ato de $\operatorname{contar}^{1}$ sujeitos ou processos sociais, está, de maneira implícita, realizando conjuntamente esses dois procedimentos.

Por um lado, é afirmada uma unidade entre fatos diversos, subsumindo-os a uma classe maior, cuja ação ou estrutura estão predefinidas, trazendo consigo expectativas e capacidade de previsão. Por outro lado, a comensurabilidade assim instituída funciona como uma ordem ideal, algo que possui um caráter vinculante (presumido e compartilhado pelos demais integrantes desse processo de comunicação) e que acarreta efeitos práticos sobre o observado. Em especial quando o ato de contar é realizado por um sujeito que pode vir a deter algum tipo de

\footnotetext{
* Este trabalho foi apresentado no Colóquio Internacional Quantificação e Temporalidade: Perspectivas Etnográficas para a Economia, promovido pelo Núcleo de Pesquisas em Cultura e Economia (NuCec), coordenado por Federico Neiburg Programa de Pós-Graduação em Antropologia Social - PPGAS) e Fernando Rabossi (Instituto de Filosofia e Ciências Sociais - IFCS), no Museu Nacional (Universidade Federal do Rio de Janeiro UFRJ), em setembro de 2005. Apesar de alterações pontuais, sugeridas pelos pareceristas de $D A D O S$ e por outros leitores, que seguramente muito serviram para esclarecer aspectos importantes, o texto mantém sua forma narrativa inicial.
}

DADOS - Revista de Ciências Sociais, Rio de Janeiro, vol. 55, nㄴ 4, 2012, pp. 1055 a 1088. 
poder ou autoridade sobre os atores e processos observados, medir é uma forma de arbitrar sobre direitos; um ato de exame e argumentação que envolve igualmente a comparação e a normatização.

No entanto, uma vez produzidos, os dados numéricos tendem a apresentar-se como desvinculados das condições em que foram gerados, como unidades absolutas de informação que podem ser exportadas para outros contextos, que permitem iluminar e explicitar deles uma nova significação. A sua dimensão normativa, que já estava antes camuflada em operações lógicas, torna-se agora inteiramente esquecida e naturalizada. No caso dos povos indígenas a história passa a ser equiparada com o automatismo de uma locomotiva, que de modo cego e inexorável atropela as alteridades e engendra os subalternos. O exame de como foram colocados os trilhos e como foi desenhado o comando da máquina é tido como inútil ou mesmo contraproducente.

Em uma leitura unilateral os procedimentos que integram a quantificação costumam ser pensados como antagônicos, estimulando uma visão excludente e simplificadora. O desafio que tento enfrentar neste artigo é fazer o caminho inverso, buscando explicitar as associações e interconexões que se estabelecem entre esses dois procedimentos, procurando mostrar como os instrumentos cognitivos são artefatos indissociáveis de jogos sociais. Trata-se de tentar uma leitura dos dados quantitativos que conjugue o esforço permanente de contextualização com a análise das rotinas e instrumentos técnicos, sem pretender ignorar ou reduzir o complexo jogo de possibilidades (inclusive com suas esferas de autonomia) que vem a instituir.

O meu objeto concreto de reflexão são os povos indígenas localizados dentro dos limites territoriais do Brasil, isto é, aquela parte da população autóctone que foi inserida no mundo colonial português na América e, no pós-independência, no processo de construção dessa nacionalidade. Em publicações diversas e em documentos históricos (referentes ao passado ou à atualidade) a parecem muitos dados numéricos sobre essas populações. Que utilidade podemos atribuir a tais dados para o estudo e a compreensão das populações indígenas?

O caráter central do trabalho de campo na antropologia e a importância da produção de dados pelo etnógrafo a partir da observação direta de fenômenos locais têm sido um valor compartilhado por diferentes escolas e correntes dentro da disciplina, funcionando como uma verdadeira doxa. Mas uma etnografia raramente se compõe de modo ex- 
clusivo com dados de observação direta, baseando-se frequentemente em descrições realizadas por observadores anteriores, lançando mão igualmente de variadas e extensas fontes escritas.

Minha preocupação, aqui, é com o uso de material quantitativo (em especial de estatísticas demográficas e fundiárias), usualmente referido a outras temporalidades distintas do presente etnográfico. Em termos mais gerais, com a relação entre antropologia e história na produção de uma interpretação que se assuma como objetiva e rigorosa.

A incorporação de dados históricos e estatísticos à narrativa etnográfica não pode ser feita de maneira acrítica e descontextualizada, equiparando-os simploriamente aos registros descritivos resultantes da observação direta. Ao mesmo tempo deslegitimar em sua totalidade o uso de tal material, pretendendo relacionar todas as interpretações apresentadas exclusivamente ao contexto etnográfico seria um exercício de miopia ou de simulação.

Ao confrontar-se com dados numéricos ou cronológicos não basta indagar-se unicamente sobre como eles podem ser dirigidos a servir aos interesses e perguntas colocadas pela pesquisa atual ${ }^{2}$, raciocinando puramente em termos de uma epistemologia positivista e deixando-se enrodilhar nas armadilhas de um pensamento realista. Há que avançar em uma direção preliminar e crítica, buscando saber de que instrumento cognitivo os dados quantitativos foram derivados, como foram efetivamente produzidos, que significados e projeções sociais estão neles cristalizados, bem como a que usos sociais serviram e servem.

Nessa linha de raciocínio a incorporação de dados procedentes de fontes escritas não pode assumir uma postura simplesmente objetivista, mas precisa tornar-se consciente de que os relatos falam da perspectiva de um observador, retratando o seu universo mental e expressando a sua relação com o observado ${ }^{3}$.

É necessário, portanto, uma antropologia dos registros numéricos que, de uma perspectiva etnográfica e crítica, os focalize enquanto produções contextuais e dotadas de intencionalidade (que apesar de limitada e parcial, não deixa de ser relevante, precisando ser recuperada e exposta). Por outro lado, tais instrumentos podem vir a possuir uma capacidade de registro e articulação entre fatos que exceda em muito as intenções e o olhar dos agentes sociais que os produziram, permitindo visualizar fenômenos novos e que estimulam a imaginação científica. 
Nesse sentido, os dados quantitativos ${ }^{4}$ existentes sobre os índios brasileiros estão associados sempre a uma preocupação com o controle social e ao avanço nas técnicas de registro e contabilidade de populações e de territórios, vinculados a um discurso da governança e da criação de condições para o exercício do poder de um soberano (ver Foucault, 1977). Só nos podem fornecer informações úteis após haverem sido adequadamente inscritos no horizonte discursivo propiciado pela implantação de um império colonial e, posteriormente, pela constituição de um Estado nacional soberano.

Este artigo irá abordar esse material quantitativo sobre os povos indígenas em três partes sucessivas: a) no aspecto demográfico, focalizado por meio de censos nacionais e levantamentos diversos, expressando uma duração relativamente longa, de quase dois séculos; b) no aspecto econômico, enquanto representado por estatísticas sobre terras, recursos ambientais e conflitos fundiários procedentes das três últimas décadas; e c) nos números, imagens e interpretações divergentes que nos últimos anos disputam as chaves para a compreensão da presença indígena no Brasil contemporâneo.

\section{CONTANDO SÚDITOS, CONTANDO CIDADÃOS}

Os primeiros relatos sobre os indígenas nessa parte da América, como a carta do "achamento", de Pero Vaz de Caminha, ou a relação de viagem pelo Amazonas do padre Acuña, estão marcados pela descrição qualitativa, ressaltando os aspectos contrastivos. Destacam os fatos de observação direta, envolvidos que estão em uma barreira linguística de comunicação. Preocupam-se também em aproximar os nativos e as suas instituições daquelas conhecidas na Europa. Apontam efetivamente grandes diferenças, mas procuram tornar o observado compreensível ao europeu, estabelecendo paralelos que não são exclusivamente negativos para os nativos, distinguido-se, portanto, bastante do discurso racializante (iniciado no século XVIII com a história natural), ou da ênfase na primitividade, própria ao discurso evolucionista, dominante no longo século XIX ${ }^{5}$. Descrevem com estupor e desagrado muitos costumes, mas com admiração alguns outros e destacam maravilhados os recursos ambientais. Quando surgem informações de natureza quantitativa, estão restritas ao potencial econômico daquelas terras, eventualmente sendo possível perceber que a intensidade da exploração econômica não é fortemente contrastante com aquela das áreas rurais da Península Ibérica. 
As informações numéricas começaram a surgir em documentos bem posteriores, elaborados por intelectuais vinculados às atividades da Coroa ou das ordens religiosas, encarregados no Novo (como no Velho) Mundo de reunir dados sobre a população e os recursos existentes nos confins do território de um soberano. Os territórios e os seus habitantes foram pensados, nessa perspectiva, como um conhecimento voltado à consolidação da rede administrativa, em geral repetindo-se nas colônias o nome das vilas e províncias da metrópole ibérica. A especificidade era que nas Américas as linhas fronteiriças ainda estavam sendo traçadas, deixando espaço aberto a políticas de expansão e conquista. O que importava descrever e contabilizar eram os recursos abrangidos pelos núcleos de colonização; o que estava além dessa fronteira era o desconhecido, a natureza agreste e não domesticada, os terrenos de povos hostis ou as posses de soberanos rivais.

Os mais abrangentes e difundidos desses relatos assumiram claramente o caráter de amplos inventários de recursos e potencialidades das áreas em processo de colonização. Um importante exemplo disso foi o livro do jesuíta João Daniel, intitulado Tesouro Descoberto do Rio Amazonas (1710). Para tais cronistas os indígenas eram populações a serem incorporadas em reinos católicos mediante um processo político-pedagógico de catequese e civilização. O que importava não era, de forma alguma, uma presumida uniformidade cultural (naquele momento inexistente nos reinos europeus), mas, sim, a aceitação dos princípios gerais da cristandade (enquanto referência partilhada pelos diferentes monarcas) e a obediência ao poder do soberano. As duas finalidades integravam, de maneira quase indissociável, o ritual político-religioso da conversão.

Os levantamentos sobre as aldeias missionárias, enquanto sentinelas avançadas da colonização, contabilizavam a população indígena pela categoria de almas, indicando assim claramente que aqueles nativos já teriam passado por um processo de batismo e de incorporação política na autoridade colonial. Há pouca preocupação em distinguir grupos locais, denominações étnicas ou localização de origem, pois a atividade missionária tem um caráter de irradiação, existindo paralelamente uma intensa circulação de famílias e pessoas indígenas para e entre as aldeias.

Outra categoria que comparece nesses levantamentos é relativa ao número de arcos existentes em cada aldeia, o que indicava a quantidade 
de homens em idade adulta capazes de serem mobilizados para a guerra contra indígenas hostis ou tropas inimigas. Isso permitia avaliar a importância militar e geopolítica de cada missão religiosa na incorporação do vale amazônico ao domínio português.

Se a contagem e localização das almas e dos arcos assumiam uma grande importância fiscal e militar para o exercício de controle local pela administração colonial, mais além desse universo de vassalos d'El Rey existia apenas o desconhecido, os indios bravos, aqueles que não tinham sido ainda alcançados ou que resistiam tenazmente à catequese. Não era possível, nem fazia sentido tentar saber quantos eram ou onde estavam os índios bravos, pois não se tratava de um atributo definitivo, mas de uma condição temporária, que remetia a trajetórias sociais antagônicas, seja pelo descimento e consequente conversão, seja pela guerra justa, com o seu extermínio, escravização ou fuga para outras regiões. Como um pagão, o índio bravo não podia ser plenamente equiparado aos humanos, sendo relativamente frouxos os controles morais e legais quanto ao tratamento que lhe era reservado. Sua relação com o terreno, ademais, era imaginada como instável e eventual, similar aos seres da natureza; só após a conversão é que poderiam vir a se configurar eventuais direitos quanto a um lugar.

Não pode ser esquecido que durante cerca de três séculos eram duas as colônias portuguesas nas Américas, a do Brasil (incluindo do litoral do atual Ceará ao Rio Grande do Sul) e a do Amazonas e Grão-Pará (incluindo o Maranhão e o vale amazônico), cada uma mantendo diretivas administrativas distintas. Os levantamentos e relatórios oficiais oferecem dados por colônias ou ordens religiosas, estando ausente a preocupação em apresentar dados unificados para o futuro território nacional. As dificuldades de comunicação e transporte também limitavam em muito a significação dos dados à escala local e regional. A prosperidade e riqueza das missões demonstrava também grande variabilidade, alterando-se continuamente e com relativa rapidez. Todos esses fatores contribuíram para justificar a limitação dos (poucos) levantamentos existentes.

No contexto pré-Independência surgiram alguns dados quantitativos sobre a população do país, resultantes não de uma iniciativa da burocracia de Estado, mas, sim, da estrutura molecular de atuação eclesiástica. Trata-se de um levantamento de paróquias e freguesias realizado pelo conselheiro Antonio Rodrigues Velloso de Oliveira entre 1815 e 
1816, que coloca algumas dificuldades para a sua transposição para as unidades político-administrativas do Império (cf. Souza e Silva, 1951). Ali se estima a população total em três milhões e seiscentas mil almas, aí incluídos os índios catequizados. Os índios bravos, que não estão contados nesse total, foram avaliados em 800 mil, o que correspondia a mais de $22 \%$ da população, deixando perceber, assim, que se tratava de uma presença significativa e que não podia ser ignorada nem pela administração, nem pelo clero. Não é de surpreender, portanto, que reflexões realizadas nos anos anteriores sobre o problema da obtenção de mão de obra para a agricultura ainda considerem a colonização e catequese dos índios como uma estratégia essencial, superior ao tráfico negreiro e à imigração de trabalhadores livres.

A participação dos índios coloniais ${ }^{6}$ no conjunto da população foi, no entanto, impossível de dimensionar, uma vez que inexistiu da parte do organizador uma preocupação em distingui-los dos demais segmentos, o que mostra que essa iniciativa continuava a se mover dentro dos instrumentos e categorias de conhecimento coloniais.

Os fatos políticos relacionados à Independência trouxeram mudanças na estrutura de poder e uma nova configuração na sociedade. A guerra enquanto instrumento de política quanto aos indígenas foi explicitamente desautorizada pelas orientações oficiais. José Bonifácio de Andrada e Silva (1992), mentor da primeira Constituição e ideólogo do Primeiro Reinado, veio a recomendar em seu clássico texto, Apontamentos para a Civilização dos Índios Bravos, que o Estado desenvolvesse uma política indigenista baseada exclusivamente em "meios brandos e suasórios". Implicitamente, o que ele censurava era a prolongada e cruenta Guerra aos Botocudos levada a cabo, há pouco mais de uma década, nos sertões do rio Doce, em Minas Gerais e Espírito Santo. Esse conflito, que durou de 1808 a 1812, resultou no quase completo extermínio dos indígenas da região, que tiveram todas as suas terras e posses confiscadas, sendo os sobreviventes distribuídos entre comerciantes locais e militares, a quem deviam servir em regime de escravidão temporária. O objetivo da atuação governamental no novo projeto deveria ser promover a civilização dos índios e torná-los úteis ao desenvolvimento nacional, o que não ocorria de modo algum com a sua exploração por mesquinhos e limitados interesses locais.

Para isso o Estado veio a definir instrumentos especiais de controle sobre os indígenas. No período da Regência, ainda antes do Segundo Rei- 
nado, um decreto (1831) estabelecia que doravante todos os pleitos relativos aos indígenas deveriam ser julgados pelos Juízes de Órfãos. No longo Segundo Reinado, apesar das variações existentes, é possível dizer que se conjugava um controle geral, feito pelo Estado por meio de uma repartição específica, a Diretoria de Civilização dos Índios, vinculada ao Ministério do Interior, e uma administração local em que era priorizado o trabalho de missionários católicos. Os dados numéricos sobre a população, agora contada através das unidades assistenciais (os aldeamentos missionários), revelavam-se muito incompletos e heterogêneos, inteiramente dependentes do interesse e dedicação de funcionários e clérigos.

\section{O ÍNDIO NOS CENSOS NACIONAIS}

No primeiro censo nacional, realizado em 1872, a presença indígena está claramente referida apenas aos índios catequizados e que já interagem normalmente com os brasileiros. Os dados sobrepõem condição civil com divisão racial, apresentando-se os homens livres divididos em brancos, negros (ex-escravos alforriados) e caboclos. Por sua vez, a população escrava subdivide-se em negros e pardos, estes últimos designando o produto de relações sexuais (maritais ou não) entre negros e brancos, ou negros e índios.

Na versão em francês das conclusões do censo de 1872, caboclo é traduzido diretamente como indien, não deixando qualquer margem de dúvida sobre os critérios acionados naquele trabalho ${ }^{7}$. Certamente os elaboradores do censo, embora estivessem operando com uma visão similar àquela que Spalding utilizava para o índio colonial, não encontraram uma expressão mais adequada em português. Outras possibilidades, como o tapuia, tinham um caráter regional (amazônico) e arcaico (século XVIII e primeira metade do XIX) ou, como índio manso, estavam em franco desuso.

O fato é que a postura protecionista pós-Independência visualizava o índio como um futuro brasileiro, isto é, como alguém que recebia (ou poderia vir a receber) alguma atenção e assistência do Estado. Daí que só caberia vir a registrar sua presença enquanto cidadão (e não como indio bravo, exterior, portanto, à sociedade) ${ }^{8}$. Mas chamar, em português, esse segmento da população simplesmente de "índios" (como no francês) não pareceria a propriado dado ao uso acusatório e estigmatizante de índio como sinônimo de índio bravo feito pelo senso comum. 
Para os estudiosos da dimensão étnica na formação do Brasil o censo de 1872 apresenta um enorme interesse. Contrastando radicalmente com a postura de muitos governadores e câmaras provinciais, que declaravam a inexistência de índios nos estados e consideravam extintos os antigos aldeamentos, bem como da elite letrada do Império, que falava do índio como algo pretérito, recuperado de modo romântico apenas nas artes e nos signos emblemáticos do país, os dados apresentados no censo de 1872 permitem apreender o peso da presença indígena nas mais variadas regiões do Brasil monárquico e escravocrata.

O censo de 1890 radicaliza ainda mais esse contraste entre dados censitários e representações da época sobre a composição étnica do país. Em

Tabela 1

Presença Indígena nos Estados (Censo de 1872)

\begin{tabular}{|c|c|c|c|}
\hline Estados & População Total & Caboclos & $\%$ \\
\hline Amazonas & 57.610 & 36.828 & 63,9 \\
\hline Pará & 275.237 & 44.589 & 16,2 \\
\hline Maranhão & 359.040 & 10.943 & 3,0 \\
\hline Piauí & 202.222 & 13.453 & 6,6 \\
\hline Ceará & 721.686 & 52.837 & 7,3 \\
\hline Rio Grande do Norte & 239.979 & 11.039 & 4,7 \\
\hline Paraíba & 376.226 & 9.567 & 2,5 \\
\hline Pernambuco & 841.539 & 11.805 & 1,4 \\
\hline Alagoas & 348.009 & 6.364 & 1,8 \\
\hline Sergipe & 176.243 & 3.087 & 1,7 \\
\hline Bahia & 1.379 .616 & 49.882 & 3,6 \\
\hline Espírito Santo & 82.137 & 5.529 & 6,7 \\
\hline Município Neutro & 274.972 & 923 & 0,3 \\
\hline Rio de Janeiro & 782.724 & 7.852 & 1,0 \\
\hline São Paulo & 837.654 & 39.465 & 4,7 \\
\hline Paraná & 126.722 & 9.087 & 7,1 \\
\hline Santa Catarina & 159.802 & 2.892 & 1,8 \\
\hline Rio Grande do Sul & 434.813 & 25.717 & 5,9 \\
\hline Minas Gerais & 2.039 .735 & 32.322 & 1,5 \\
\hline Goiás & 160.395 & 4.250 & 2,6 \\
\hline Mato Grosso & 60.417 & 8.524 & 14,1 \\
\hline Total & 9.930 .478 & 386.955 & 3,8 \\
\hline
\end{tabular}

Fonte: Elaboração do autor com base nos dados do IBGE, censo de 1872. 
quase todos os estados, e no geral, os dados apontam um aumento bastante significativo da presença indígena na população total. Alguns demógrafos e historiadores preferiram explicar isso mediante a suposição de menos rigor e de erros na condução do censo. Levantamos aqui uma hipótese diversa.

O censo de 1890, posterior a fatos marcantes na história do país, como a abolição da escravatura e a proclamação da república, opera com outras categorias e em um contexto político e racial bastante modificado. Todos os cidadãos recenseados eram legalmente livres, distinções entre eles podendo ser estabelecidas apenas pela cor (que pela multiplicidade de indicadores físicos que comporta - cor da pele, forma do cabelo, nariz, crânio etc. - se presta à ambiguidade e inclusive à incorporação de características sociais a um complexo jogo classificatório).

A categoria caboclo continuava a existir, mas não ocupava mais um campo semântico que a oporia ao escravo (agora inexistente), mas, sim, localizada em um gradiente de cor, tendo ao seu lado brancos, negros (isto é, descendentes de escravos) e pardos (que, nesse caso, indicaria a condição de mestiço, filho de branco com negro). Para todos aqueles que não eram enquadrados como brancos ou negros apresentavam-se assim duas opções: a de figurar como pardo (que em termos de significados sociais difusos conotava a sua proximidade com a condição escrava), ou como caboclo (destacando a sua proximidade com os indígenas). Não deve causar surpresa o forte crescimento relativo da categoria caboclo, aumento bem superior ao da taxa de crescimento demográfico, pois no período imediatamente posterior à abolição essa seria, sem dúvida, a opção classificatória mais favorável em termos sociais para os mestiços.

Há ainda um outro fator a considerar. Não era apenas na categoria de caboclos que estavam colocados os indígenas no censo de 1872, mas também figuravam secundariamente na condição de pardos. Nesses casos não se tratava de população livre, mas, sim, de escravos. Diversas fontes indicam que uma maneira empregada por interesses locais para camuflar a escravização de indígenas (inteiramente ilegal no pós-Independência) era celebrar o casamento de indígenas (livres) com negros (não alforriados), passando a sua prole à condição de escravos do agenciador desse arranjo. Os dados disponíveis não permitem, porém, quantificar o peso desse estratagema social. Após a abolição esse con- 
tingente de pardos, migrando para a categoria de caboclos, poderia sinalizar um vínculo com os indígenas.

Tabela 2

População Nacional por Cor

(Censos de 1872 e 1890)

\begin{tabular}{l|c|c|c|c}
\hline Cor & $\mathbf{1 8 7 2}$ & $\mathbf{\%}$ & $\mathbf{1 8 9 0}$ & $\%$ \\
\hline Brancos & 3.787 .289 & 38,1 & 5.538 .839 & 40,8 \\
Pretos & 1.954 .452 & 19,7 & 2.097 .426 & 15,4 \\
Pardos & 3.801 .782 & 38,3 & 4.638 .545 & 34,2 \\
Caboclos & 386.955 & 3,9 & 1.295 .796 & 9,6 \\
\hline Total & $\mathbf{9 . 9 3 0 . 4 7 8}$ & $\mathbf{1 0 0}$ & $\mathbf{1 3 . 5 6 0 . 6 0 6}$ & $\mathbf{1 0 0 , 0}$ \\
\hline
\end{tabular}

Fonte: Elaboração do autor com base nos dados do IBGE, censos de 1872 e 1890.

Nos censos nacionais consecutivos o caboclo deixou de figurar como uma das alternativas classificatórias maiores, passando a estar contido como uma das possibilidades da categoria pardo, que com isso passou a se aplicar a toda e qualquer forma de mestiçagem. Dessa forma, de 1890 até o ano de 1940 inexistem nos censos dados específicos sobre os indígenas que habitavam o território nacional ${ }^{9}$.

\section{O INDIGENISMO REPUBLICANO E O REGIME TUTELAR}

Com o advento da República começa, no entanto, a delinear-se um novo cenário para a política indigenista brasileira. Enquanto a Constituição transferia aos estados o controle das terras devolutas (nas quais habitavam a grande maioria dos índios, seja em antigos aldeamentos, seja pelos sertões adentro), toda a preocupação se deslocava, outra vez, para os índios bravos, isto é, aqueles que por seus costumes se distinguiam radicalmente dos brasileiros e não obedeciam à autoridade nacional.

As áreas onde estavam localizados tais indígenas, que eram então objeto de interesse do Estado brasileiro, não eram de modo algum aquelas de colonização mais antiga, mas justamente ao contrário, aquelas situadas na linha da expansão recente das fronteiras econômicas interiores do país, contrapondo-se à ação das frentes pioneiras, bem como à construção de estradas, ferrovias e empreendimentos estratégicos. O problema indígena passou a ser visto como uma questão de expansão da fronteira, sobretudo do Norte e do Centro-Oeste, afetando empreendimen- 
tos de interesse crucial da União, que precisava agir diretamente sobre os conflitos que estavam se sucedendo ${ }^{10}$.

Um projeto de constituição elaborado por Teixeira Mendes, destacado pensador positivista, atribuiu bastante relevo às formas políticas e culturais dos povos indígenas, ao reconhecê-los como estados americanos autóctones, que deveriam vir a integrar o Estado federativo republicano. Embora essa proposta não fosse apreciada, veio a marcar uma ascendência dos positivistas sobre a temática indigenista, logo consolidada pela atuação do engenheiro militar Cândido Mariano da Silva Rondon no contato e pacificação de tribos isoladas nos estados de Goiás e Mato Grosso e no território do Guaporé (depois Rondônia). A forma de intervenção cunhada durante esses trabalhos transformouse na base da criação de uma agência indigenista federal, em 1910, o Serviço de Proteção ao Índio (SPI) ${ }^{11}$, cuja equipe era constituída por colaboradores mais próximos de Rondon, em geral militares e positivistas.

De que dados quantitativos dispunham Rondon e seus colaboradores no SPI? A atuação indigenista era bastante heterogênea nas diferentes regiões, e os dados de que dispunham resultavam, sobretudo, de situações locais, isto é, dos Postos Indígenas. Ainda durante a comemoração do centenário da independência, os trabalhos sobre a população brasileira (Carneiro, 1922; Garcia, 1922) mencionavam a estimativa feita por Rondon de 1,5 milhão de indígenas. Certamente não resultante dos dados esparsos e fragmentários de que dispunha o SPI, mas de uma aproximação resultante do censo de 1890, que falava em 1,3 milhão caboclos (enquanto Rondon pensava de fato a partir do índio bravo).

A inadequação desses números tornou-se patente nas décadas de 1940 e 1950, quando os censos nacionais lançaram mão de uma outra coleta que permitia uma a proximação relativamente mais fina ao contingente de indígenas existente no país nesse período. Em função da Segunda Guerra Mundial e da preocupação do governo com a compacta presença de alemães e italianos no Sul do país ${ }^{12}$, foi inserida nesses censos uma pergunta sobre o uso de língua estrangeira dentro das unidades familiares. Trata-se da variável "pessoas que no lar falam outra língua além do português". Entre alternativas de línguas estrangeiras (europeias, asiáticas e outras) existia um item para os que falassem "guarani ou qualquer outra língua aborígene". Esta última foi a situação de 3,5\% dos recenseados que declararam não falar o português dentro de sua 
própria casa, correspondendo então a um inequívoco contingente de 58.027 indígenas. No censo de 1950 este número se reduziu para 46.208 , e não foi mais coletado nos censos posteriores. Um rápido exame dos números apresentados nos dois censos mostra uma relativa coerência, em sua maioria com pequenas oscilações para baixo verificadas no censo de 1950. São exceções a isso os acréscimos (também pequenos) registrados no Acre, Maranhão e Santa Catarina. O aspecto

Tabela 3

Pessoas que Não Falam o Português Habitualmente no Lar, mas Sim Línguas Indígenas, por Estado da Federação

\begin{tabular}{|c|c|c|}
\hline Estados & 1940 & 1950 \\
\hline Acre & 1.038 & 1.300 \\
\hline Amazonas & 1.231 & 19.563 \\
\hline Pará & 22.721 & 704 \\
\hline Maranhão & 3.518 & 4.409 \\
\hline Piauí & - & 1 \\
\hline Ceará & 2 & 1 \\
\hline Rio Grande do Norte & - & 0 \\
\hline Paraíba & - & 0 \\
\hline Pernambuco & 562 & 458 \\
\hline Alagoas & - & 0 \\
\hline Sergipe & 1 & 0 \\
\hline Bahia & 117 & 10 \\
\hline Minas Gerais & 297 & 141 \\
\hline Espírito Santo & 42 & 0 \\
\hline Rio de Janeiro & 15 & 0 \\
\hline Distrito Federal & 26 & 15 \\
\hline São Paulo & 401 & 216 \\
\hline Paraná & 2.986 & 2.371 \\
\hline Santa Catarina & 373 & 618 \\
\hline Rio Grande do Sul & 2.100 & 2.347 \\
\hline Goiás & 1.805 & 1.052 \\
\hline Mato Grosso & 20.792 & 11.473 \\
\hline Guaporé & & 28 \\
\hline Rio Branco & & 1.024 \\
\hline Amapá & & 477 \\
\hline Brasil & 58.027 & 46.208 \\
\hline
\end{tabular}

Fonte: Elaboração do autor com base nos censos de 1980 e 1950, do IBGE. 
confuso fica por conta dos estados do Amazonas, Pará e Mato Grosso, todos com grande população indígena, cujas variações parecem injustificadas.

Os dados utilizados pelo SPI só irão modificar-se já no correr da década de 1950, quando o antropólogo Darcy Ribeiro coordenou um levantamento sobre a população indígena baseado nas fichas administrativas das unidades do SPI (Postos Indígenas e Inspetorias). Nesse trabalho, concluído em 1957, era apontada a existência em todo o território nacional de 143 etnias, com uma população estimada entre 68.100 e 99.700 indivíduos (Ribeiro, 1970:258). Tais números, pelo menos em seu limite inferior, não eram muito discrepantes daqueles apresentados nos dois censos linguísticos de 1940 e 1950, sobretudo se considerarmos que, por problemas de coleta nos estados do Amazonas, Pará e Mato Grosso, já comentados acima, a população indígena estava subestimada.

Os dados do SPI falam também de 21 povos isolados e apresentam informações apenas sobre 110 etnias. Desse conjunto, 52 povos indígenas, ou seja, quase a metade desses, possuía uma população inferior a 250 pessoas; no outro extremo da escala demográfica estavam as maiores populações, em uma faixa de povos com mais de duas mil pessoas, e que eram apenas seis.

A imagem que a sociedade brasileira tinha dos povos indígenas, refletindo o discurso e as estatísticas do SPI, era de pequenas e frágeis microssociedades que viviam isoladas no interior da floresta amazônica. Ameaçadas por um processo doloroso e inexorável de aproximação da civilização, caberia ao Estado evitar o seu completo extermínio e protegê-las das frentes de expansão econômicas. Até sua classificação administrativa era feita segundo o grau de contato, em uma linha evolutiva que ia da condição de isoladas a té a de integradas, em um quadro absolutamente compatível com o indigenismo tutelar e suas formas de ação e conhecimento ${ }^{13}$.

\section{TERRAS INDÍGENAS: UM COPO MEIO CHEIO OU MEIO VAZIO?}

No processo de tornar públicos os seus fins e legitimar as suas ações o SPI apoiou-se muito na figura emblemática de Cândido Mariano da Silva Rondon, que por sua trajetória profissional conseguia conjugar mensagens distintas para públicos diferentes. Para a opinião pública Rondon apresentava-se como um abnegado idealista, um santo soldado, 
ou um missionário leigo ${ }^{14}$ que em seu prolongado trabalho no interior dos sertões estabeleceu um modo humanitário e inovador de relacionamento com os índios. Por outro lado, sua carreira como militar disciplinado e, depois, como gestor da agência indigenista (SPI), lhe assegurava o reconhecimento e a confiança de amplos e fortes setores da burocracia de Estado. À diferença de seus colaboradores ou de outros sertanistas que o sucederam ${ }^{15}$, Rondon funcionou como um símbolo de uma política governamental, vindo a condensar em si tanto as imagens românticas e nativistas presentes no imaginário brasileiro quanto o realismo e responsabilidade necessários a um administrador eficiente. A atual agência indigenista, Fundação Nacional do Índio (Funai), surgida após a morte de Rondon, e a grave crise ocorrida na década seguinte (que culminou com sua extinção por meio de uma rumorosa CPI), jamais contou com esse capital simbólico que lhe permitisse gerenciar uma política pública com alto grau de legitimidade e sem sofrer fortes questionamentos.

Durante o final dos anos 60 e em toda a década seguinte, a Funai e o governo militar sofreram fortes críticas das imprensas nacional e internacional, sendo objeto de denúncias e investigações, bem como tendo que enfrentar uma ampla mobilização de setores da opinião pública contra a sua política indigenista, expressada na minuta de decreto sobre a emancipação dos índios (elaborada em 1979, pelo então ministro do Interior, Rangel Reis).

É nesse quadro de retomada dos direitos civis e fortalecimento dos movimentos sociais que surgiu o primeiro levantamento sobre as terras habitadas pelos indígenas, realizado por funcionários da Funai e divulgado por uma publicação oficial, um livro ricamente ilustrado e bastante informativo, projetado para tentar mudar a imagem do órgão junto aos formadores de opinião (Funai, 1981).

As informações sobre as terras indígenas eram apresentados de forma simples e direta, integrando um conjunto de dados sobre a estrutura administrativa (composta por 163 Postos Indígenas, 18 Postos de Atração, 13 Delegacias Regionais, dois Parques Indígenas e uma Ajudância Autônoma) e as atividades assistenciais (de proteção tutelar, saúde e educação) desenvolvidas pelo órgão. As áreas indígenas, em número de 256, foram listadas por unidades administrativas, em dados brutos que pareciam resultar de uma simples agregação de relatórios parciais produzidos por essas unidades, contendo informações sobre localiza- 
ção geográfica (estado e município), estimativas de população e de superfície.

Os dados gerais sobre população e terra resultavam de uma soma simples, não recebendo nenhum comentário ou tentativa de análise. Quanto à população, estimada em 145.397 pessoas, poderia ser feito um paralelo com o levantamento realizado por Darcy Ribeiro na década de 50, mostrando que em cerca de três décadas a população indígena haveria crescido bastante, quase duplicando. Por seu ineditismo, o dado geral sobre terra indígena, situado na ordem de 41 milhões de hectares (ha), não veio a receber uso algum, exceto aquele genérico de realçar a amplitude e a eficiência da ação protecionista do indigenismo tutelar.

No ano seguinte o Conselho Indigenista Missionário (CIMI), órgão vinculado à Igreja Católica e bastante crítico quanto à Funai e à política indigenista oficial, divulgou uma outra listagem de terras indígenas. Em sua origem, os dados eram basicamente os mesmos, procedentes do levantamento feito pela Funai em 1981. As modificações eram de pequena monta, afetando principalmente correções nos dados de populações verificadas em algumas áreas de atuação do CIMI.

A leitura e a organização dos dados, no entanto, era bem diferente da publicação da Funai, avançando uma interpretação radicalmente oposta. As áreas indígenas eram enumeradas não de acordo com as unidades administrativas da Funai, nem com as unidades políticas brasileiras (estados e municípios), mas seguindo uma classificação por área cultural, produzida com finalidades inteiramente diversas pelo etnólogo Eduardo Galvão (1979). Embora possua uma utilidade museológica e sirva também para a classificação de material etnográfico, a ordenação proposta é pouco operacional para a localização e articulação de dados. Possui, contudo, um claro efeito ideológico, ao tentar deslegitimar a Funai enquanto fonte exclusiva de dados sobre os índios brasileiros e colocar explicitamente em questão a unidade entre tutor e tutelado.

O texto elaborado, à diferença daquele da Funai (meramente de divulgação e propaganda), pretende ter um caráter mais opinativo e analítico. É comentado que o total de população ali apresentado (185.485 pessoas) indicaria um forte crescimento demográfico face aos dados de 1957, em que pesem as precárias condições de assistência existentes. Quanto às terras indígenas, foram somadas apenas aquelas que já esta- 
riam demarcadas, totalizando apenas 12, 3 milhões de hectares. Isso permitiu mostrar que a proteção oficial às terras habitadas pelos índios ocorria somente para $46 \%$ da população indígena estimada.

As terras indígenas situadas em fases anteriores dos procedimentos administrativos foram apresentadas como "sem informação", considerando que os dados ali contados seriam apenas provisórios e parciais. A conclusão final é bastante contundente, apontando a morosidade como característica dos processos de reconhecimento de terras indígenas conduzidos pela Funai e a sua ineficiência no exercício de uma tutela protetora.

A partir de então as estatísticas sobre terras indígenas passam a estar no centro dos debates sobre a política indigenista brasileira, assumindo o lugar de um indicador privilegiado, usado como eficiente arma política, retomado pelos vários atores sociais e sempre com sentidos diferentes. Ainda em 1982 uma revista de empresários rurais de Mato Grosso atacou vigorosamente a Funai por transformar cerca de 14\% do estado em terras indígenas, reivindicando mudanças urgentes nessa política que estaria obstruindo o desenvolvimento regional. Manifestações semelhantes ocorreriam nos anos seguintes em outros estados e territórios (Pará, Amazonas e Roraima) através de associações de empresários e autoridades regionais.

Em 1983 um decreto presidencial retirou da Funai o poder de criar terras indígenas com base no critério exclusivo de posse imemorial e instituiu uma nova sistemática legal (Decreto no 81.118/1983). Os processos de criação de terras deveriam agora passar pela aprovação de um grupo técnico interministerial (no qual a Funai tinha assento juntamente com o Ministério do Interior e a Secretaria Especial de Assuntos Fundiários, vinculada esta ao Conselho de Segurança Nacional (CSN) e à Secretaria Geral da Presidência da República). Tal grupo, por sua vez, estava subordinado a diferentes instâncias administrativas (aprovação dos ministros) e deveria levar em conta igualmente o critério de situação atual das áreas reivindicadas, bem como avaliar o seu possível impacto para o desenvolvimento e a segurança nacional.

Instala-se uma verdadeira guerra dos números, que na realidade corresponde à multiplicidade de leituras por diferentes atores sociais dos mesmos dados coligidos pela Funai. Funcionários do CSN, em documentos sobre a temática, fizeram criticas à extensão, que reputavam excessiva, das áreas indígenas, baseados no indicador numérico hecta- 
res/índio, o qual ultrapassava em muito os parâmetros estabelecidos pelo Instituto Nacional de Colonização e Reforma Agrária (Incra) para a definição de módulos rurais. Durante a elaboração da nova Carta constitucional a Funai dirigiu uma mensagem aos parlamentares solicitando que o artigo 198 da antiga Constituição não fosse repetido no novo texto, identificando-o como causa de enorme desgaste administrativo para o órgão indigenista. Foram traçados longos paralelos entre o tamanho das áreas indígenas e a superfície de alguns países europeus, pretendendo, assim, demonstrar-se o descalabro que resultaria da manutenção dos critérios existentes.

Uma investigação iniciada em 1985 por antropólogos do Museu Nacional e do Centro Ecumênico de Documentação e Informação (CEDI) vai empreender a construção de um banco de dados sobre terras indígenas, organizado fora do controle da Funai, em grande parte informatizado e guiado pelos princípios da transparência e da democratização dos dados. Na apresentação da publicação Terras Indígenas no Brasil, que contém uma listagem atualizada e revisada, estão escritos os procedimentos adotados:

A documentação oficial (sobre terras indígenas) nunca esteve organizada de modo sistemático e acessível aos interessados, exceto durante curtos períodos na administração do órgão indigenista. O quadro [...] aqui apresentado foi inteiramente montado a partir de publicações oficiais (Diário Oficial, Boletim Administrativo, Atos Legislativos e documentos diversos encontrados no Congresso Nacional e em ministérios relacionados), a sua constituição funcionando como um verdadeiro teste dos informes anuais feitos pela Funai para outros órgãos governamentais e agências de fomento. Os dados obtidos de diferentes fontes, com gêneros e destinações específicas, foram reunidos e comparados através de uma avaliação criteriosa, complementada por informações provenientes da rede de colaboradores, sendo assim depurados os incontáveis equívocos verificados (que vão de erros no registro do território, população ou localização dos grupos, até grafias e formas múltiplas de referência a povos e grupos locais) e explicitadas as dúvidas e ambiguidades que por ora ainda não se conseguiu superar. A descrição da metodologia de trabalho adotada nessa pesquisa está apresentada na Nota Metodológica que acompanha essa listagem. (Pacheco de Oliveira, 1987a:7)

A listagem das terras indígenas apresentada em 1987 pelo PETI/Museu Nacional ${ }^{16}$ e CEDI $^{17}$, além de trabalhar com um banco de dados 
próprio, traça um quadro muito distinto daquele resultante do levantamento da Funai (1981). O número de terras indígenas listadas efetivamente dobrou, passando de 256 a 518, resultando esse crescimento tanto de um controle mais rigoroso sobre os processos administrativos em curso na Funai (95 casos), quanto da inclusão de demandas localizadas ainda não contempladas pela atuação desta (167 casos).

Duas consequências disso merecem ser assinaladas. Em primeiro lugar, a ampliação do universo de áreas inventariadas (95 casos) implica significativo aumento da extensão total das terras indígenas, que passam de 41 para 74,4 milhões de hectares, registrando um aumento de $81 \%$. Em uma reedição (revisada e atualizada) dessa listagem no ano de 1990 o número de terras aumenta pouco, ficando em 526, a extensão total subindo para 79,3 milhões de ha.

Em segundo lugar, e mais importante ainda, ao incluir nesse inventário as terras reivindicadas pelos índios (ainda que não identificadas pela Funai) a listagem transforma-se em um instrumento de reconhecimento de direitos e de identidades locais, de caráter aberto e que opera com independência face ao governo. Embora sua eficácia seja apenas virtual (pois é à Funai que cabe, em última instância, a tarefa de demarcar as terras indígenas), a listagem tira do limbo administrativo reivindicações políticas quanto ao reconhecimento de direitos pelo Estado, dando visibilidade à existência dessa demanda junto à sociedade e aos atores interessados. A listagem criaria, inclusive, uma agenda de trabalhos para a agência indigenista, o que se tornou claro com a significativa redução das áreas não identificadas (que na publicação de 1990 passa a ser de 90 , isto é, uma redução de mais de um terço em apenas três anos). Em poucos anos a metodologia de trabalho utilizada pelo $\mathrm{Mu}-$ seu Nacional e CEDI, apoiada pelos indígenas e pela opinião pública, e legitimada pela academia, foi difundida e generalizou-se, sendo adotada inclusive pela Funai. Tornado transparente e democrático, o banco de dados foi duplicado por diversas outras entidades não governamentais (como a Operação Amazônia Nativa - OPAN, a Associação Nacional de Ação Indigenista - ANAI-BA, e o Conselho Indigenista Missionário - CIMI).

Enquanto as terras indígenas tornavam-se mais e mais o centro de todas as disputas sobre a política indigenista, os dados de população tornaram-se de interesse cada vez mais secundário. Constavam nas duas listagens produzidas pelo Museu Nacional e CEDI estimativas de po- 
pulação, indicando, em 1987, um total de 213 mil índios, enquanto em 1990 eram mencionados $235 \mathrm{mil}^{18}$. A pouca ênfase no dado demográfico nessas publicações derivava da heterogeneidade de fontes utilizada, correspondendo também somente a uma estimativa, diferentemente dos dados sobre terra, registrados com precisão cartográfica em documentos de valor jurídico e administrativo.

Na década seguinte, toda a atenção dos atores sociais e políticos que atuavam no campo indigenista se concentraria na discussão das terras, menos no aspecto de seu dimensionamento e mais nos critérios que deveriam orientar a sua criação. Uma nova sistemática administrativa (Decreto no $1.775 / 1996$ ) veio a regular todo o processo de estabelecimento das terras indígenas atendendo a múltiplos interesses. Por um lado, contemplava os reclamos de proprietários, autoridades locais e seus representantes jurídicos ao introduzir nos procedimentos técnicos uma fase para a apresentação pelos possíveis prejudicados de provas contrárias (chamada de direito ao contraditório). Por outro, trazia importantes aperfeiçoamentos aos procedimentos técnicos, dando ao trabalho do antropólogo um lugar central na identificação de terras e incorporando também à equipe um especialista ambiental (ou seja, pela primeira vez pensando a terra indígena em seu aspecto de carrying capacity (capacidade de carga) e no aspecto da conservação dos recursos naturais.

Foi criada na Funai, graças a recursos do Projeto Piloto para as Florestas Tropicais e provenientes do G-7, da União Europeia, do Banco Mundial e da agência de cooperação alemã (GTZ) e inglesa (DFID) um setor relativamente especializado que passou a se ocupar da demarcação e fiscalização das terras indígenas na região amazônica. Entre 1997 e 2001, através de 10 projetos executados no Amazonas, Acre e Pará chegariam a ser demarcados 22,7 milhões de hectares (ver Pacheco de Oliveira, 1998 e 2006) dentro de uma política mais global em que as áreas indígenas eram pensadas enquanto uma modalidade de unidade de conservação. Todas as unidades de conservação existentes na Amazônia até 2001, incluindo as federais e as estaduais, as de uso indireto ou direto, totalizavam 64,5 milhões de ha (ou 12,9\% da superfície da Amazônia Legal), enquanto as terras indígenas por si só perfaziam 100,2 milhões de ha (isto é, $20 \%$ da região) ${ }^{19}$.

Em um dado recente (2004) a Funai, utilizando-se agora de categorias e de uma metodologia muito próxima daquela das listagens do Museu 
Nacional e CEDI (1987 e 1990), fala em 599 terras indígenas em diferentes fases do processo demarcatório, cuja extensão totalizaria 101,4 milhões de ha. Destas, cerca de 98,8\% estariam situadas na região amazônica, na chamada Amazônia Legal.

\section{ESTATÍSTICAS E IMAGENS CONFLITANTES}

Nos últimos anos manifestou-se uma abissal diferença entre as imagens de Brasil que eram propiciadas pelas diferentes estatísticas quanto aos indígenas. Os instrumentos cognitivos construídos ao longo de década para contar população ou para mensurar terras parecem conduzir a conclusões radicalmente polarizadas. Qual a origem e a relevância sociológica desse conflito?

Desde o censo de 1890 que a agência nacional responsável pelas estatísticas de população abandonou a ideia de fazer uma contagem em separado da população indígena. É paradoxal que isso tenha acontecido logo após um censo que indicava como significativa - mesmo em termos quantitativos $(9,6 \%)$ - a presença indígena na população brasileira. A República utilizou-se algumas vezes de símbolos ocidentais e imagens cosmopolitas para marcar sua contraposição aos signos nativistas empregados nos emblemas do Império do Brasil. O fato é que uma análise do censo de 1890 não deixa dúvida quanto à intenção dos que o planejaram em contribuir para dar ao país uma "cara republicana", onde os cidadãos seriam todos iguais, independente de raça (ou de seu eufemismo cor). Assim, o censo nacional de 1900, ocorrido na virada do século, e o seguinte, de 1920, próximo às celebrações de um século de independência, ignoraram a variável cor e não operaram com qualquer distinção étnico-racial.

Só a partir de 1940 é que ressurgiu tal distinção, primeiro de forma residual, quase envergonhada ${ }^{20}$, de modo a indicar as situações de mestiçagem. O termo pardo foi assumido enquanto um grupo censitário, o qual será o único a expandir-se em termos proporcionais de modo contínuo, chegando a atingir 38,9\% em 1980, materializando assim no contexto brasileiro a perspectiva assimilacionista do melting pot (Glazer e Moynihan, 1963). As séries estatísticas propiciadas pelos censos sugeriam que o Brasil era um país crescentemente misturado, onde os brancos ainda se mantinham como maioria, mas onde os negros estavam em acentuado declínio $(5,9 \%)$ e os índios, por sua presença escassa, dispersa e confinada nos rincões extremos do país, eram vistos como 
quantitativamente irrelevantes. Tornaram-se portanto, invisíveis ao censo.

Em todo esse ínterim inexistiram estatísticas gerais e confiáveis sobre os índios do Brasil. A estimativa genérica feita por Rondon e baseada no censo de 1890 tinha, sobretudo, uma finalidade política (de expressar o peso do indígena no país) e apoiava as demandas da agência indigenista por recursos e apoio. O minucioso levantamento realizado por Darcy Ribeiro ${ }^{21}$ evidenciou uma outra realidade - a pequena significação demográfica da população indígena, bem como sua fragmentação em coletividades reduzidas e isoladas na floresta. Os índios do SPI traziam para o presente, sem as conotações negativas e criminalizantes, as antigas imagens coloniais sobre o índio bravo. Eram justamente essas características que inviabilizavam que o Instituto Brasileiro de Geografia e Estatística (IBGE) viesse a especificar os indígenas dentro do processo censitário.

Nos anos 80 a atenção da opinião pública e das autoridades (nacionais e internacionais) se volta para os índios, mas abordando-os principalmente segundo o prisma dos recursos ambientais que detêm ou que reivindicam. A preocupação dominante será a de medir as suas posses e demandas quanto a terra. É isso que será intensamente disputado nas três últimas décadas, ampliando em muito a significação econômica e política dos indígenas, mas mantendo a imagem produzida pelo antigo SPI. O discurso ecológico continuará a apoiar-se na representação do índio bravo, depurada de uma maldade e belicosidade congênita que lhe era atribuída pelo discurso colonial. A obra de Rondon e dos sertanistas foi de ressemantizar o índio bravo, transmutando-o no índio dócil e colaborativo ao qual o discurso ecológico irá acrescentar um novo significado, o de protetor do meio ambiente.

Em 1991, em consequência de análises aprofundadas sobre as estatísticas relativas à questão racial no Brasil ${ }^{22}$ e em resposta a pressões dos movimentos sociais, o IBGE modificou o critério de atribuição étnica, passando a operar com o mecanismo da autoclassificação. As respostas possíveis à pergunta sobre cor permitiam, a partir de então, que o entrevistado se identificasse enquanto branco, negro, amarelo, pardo ou índio. Em termos gerais, os dados apresentados não chegavam a ser discrepantes das estimativas sobre a população indígena fornecidas pela Funai ou pelo Museu Nacional e CEDI. Assim, o IBGE falava em 294 mil indígenas, desses, cerca de dois terços habitando em áreas ru- 
rais, um número pouco inferior às estimativas realizadas pela FUNAI. Quanto aos índios que habitavam em cidades, da ordem de 71 mil, não se dispunha de qualquer levantamento anterior que pudesse dimensionar o fenômeno, não havendo base para questionar os dados obtidos pelo IBGE.

Foi com a divulgação dos resultados do censo de 2000 que se instalou uma profunda perplexidade. Por esses dados, o total de brasileiros que se autodeclaravam indígenas correspondia a mais que o dobro daqueles que figuravam nos quadros elaborados pela Funai e pelas ONGs, todos esses últimos operando com uma metodologia similar e baseada no monitoramento das terras indígenas. Enquanto o censo de 2000 realizado pelo IBGE encontrou 734 mil índios no país, a Funai, em 2004, continuava a estimar a população indígena em 323 mil, agregando a isso apenas a ressalva de que não estava computando os índios urbanos. O Mapa das Terras Indígenas, elaborado pela Funai, atualizado para 2012, retirado do seu site oficial, permite visualizar os espaços étnicos, reconhecidamente indígenas, existente no território nacional.

\section{Mapa 1}

Mapa das Terras Indígenas do Brasil

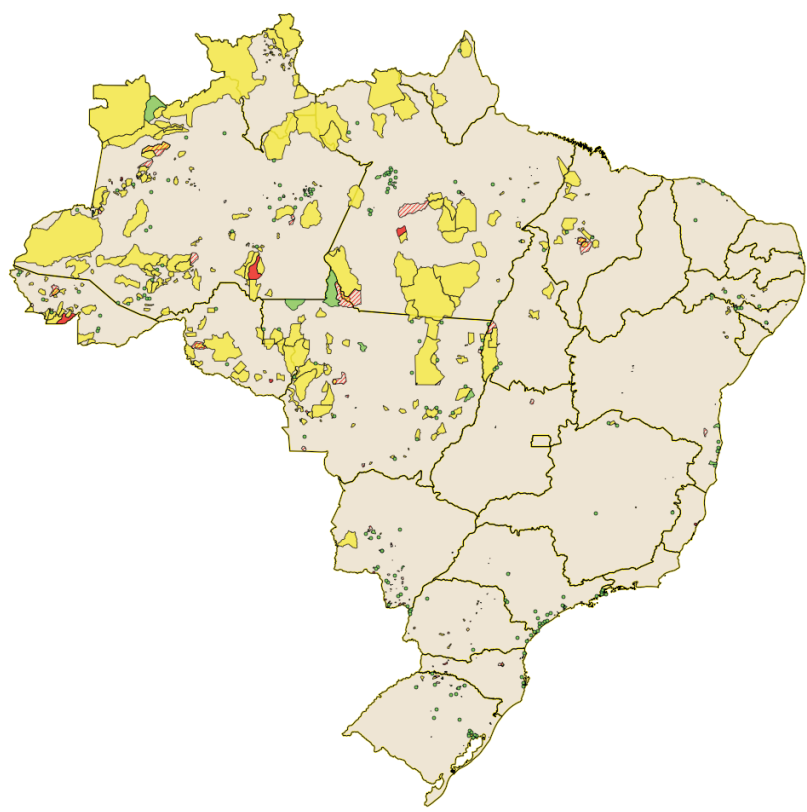

$\square$ Declarada

$\square$ Delimitada

$\square$ Encaminhada RI Homologada

- Em estudo Ponto $\square$ Regularizada $N$ Limite Estadual Brasil

Fonte: Funai (2012). 
O censo de 2000 traz duas grandes novidades frente aos mapas de terras indígenas e as estimativas de população daí derivadas. Primeiro, indica um vertiginoso crescimento dos índios que moram em cidades (383 mil), o que em números absolutos representa mais de cinco vezes o contingente de 1991, bem como sua duplicação em termos proporcionais. Com isso, inclusive os índios urbanos passam a ser mais numerosos $(52,2 \%)$ do que os indígenas que vivem no meio rural.

A relação dos estados onde é mais numerosa a população de índios urbanos surpreende os estudiosos. Entre os sete primeiros, em ordem decrescente - São Paulo, Bahia, Minas Gerais, Rio de Janeiro, Pernambuco, Rio Grande do Sul e Paraná -, não está qualquer dos estados onde se localizam as mais extensas terras indígenas, nem aqueles que sejam objeto de atenção especial da política indigenista. Só em uma segunda faixa, entre 10 e 20 mil declarantes, é que aparecem Amazonas, Goiás, Pará e Mato Grosso do Sul.

Segundo, mesmo as estimativas baseadas nas terras indígenas demonstram-se acanhadas em relação aos declarantes que moravam no meio rural, cujo contingente (350 mil) é superior em mais de $10 \%$ à estimativa com que opera a Funai. Essa diferença não resulta de um único estado ou região, mas estende-se por todo o Brasil, evidenciando a existência em número expressivo de pessoas que mesmo residindo fora das terras indígenas se assumem como índios.

Até o ano de 2005, quando indagados sobre a disparidade de números entre Funai e IBGE quanto aos indígenas no Brasil, os dirigentes da Funai costumavam qualificar os dados do IBGE como errôneos, enfatizando a falta de preparo de suas equipes de campo para lidar com a temática indígena. Sem dúvida, uma melhor preparação dos entrevistadores nesse quesito poderia tornar mais rigorosos os dados do futuro censo nacional, mas isto não é razão para invalidar os resultados já obtidos.

\section{CONSIDERAÇÕES FINAIS}

É preciso compreender que se constituem em instrumentos cognitivos distintos, com metodologias diferentes e que respondem a interesses e ideologias também distintas, articuladas com redes sociais que podem ter finalidades divergentes. Os dados que se expressam nessas imagens e interpretações contraditórias não devem ser abordados de uma perspectiva excludente, como se fossem uns exatos e outros falsos, 
nem com a intenção de aferir o grau de verdade de cada. A meu ver, trata-se de compreender que ali se expressam diferentes formas de conceber os indígenas no Brasil, que correspondem a projetos políticos e que operam com temporalidades distintas.

O que os dados produzidos pelo IBGE permitem visualizar são fatos que estão muito além da estrutura tutelar da Funai ou das redes de articulação estabelecidas pelas ONGs dentro de uma perspectiva assistencial, de desenvolvimento ou conservacionista. A sua importância não se restringe a chamar atenção para um movimento crônico de migração que leva pessoas e famílias indígenas do meio rural para as áreas urbanas. É preciso que esse deslocamento geográfico seja inserido em um processo maior, de longa duração, de incorporação dos indígenas em múltiplos nichos da sociedade brasileira, seja no campo (nas cercanias de sua área de origem ou muito afastados dela), seja nas cidades (e não apenas nas capitais, mas nas pequenas cidades de interior).

A distribuição da população indígena recenseada pelo IBGE segundo os municípios mostra a extensão dessa presença indígena nas mais di-

\section{Mapa 2}

Mapa dos Municípios Brasileiros por Percentual de Indígenas

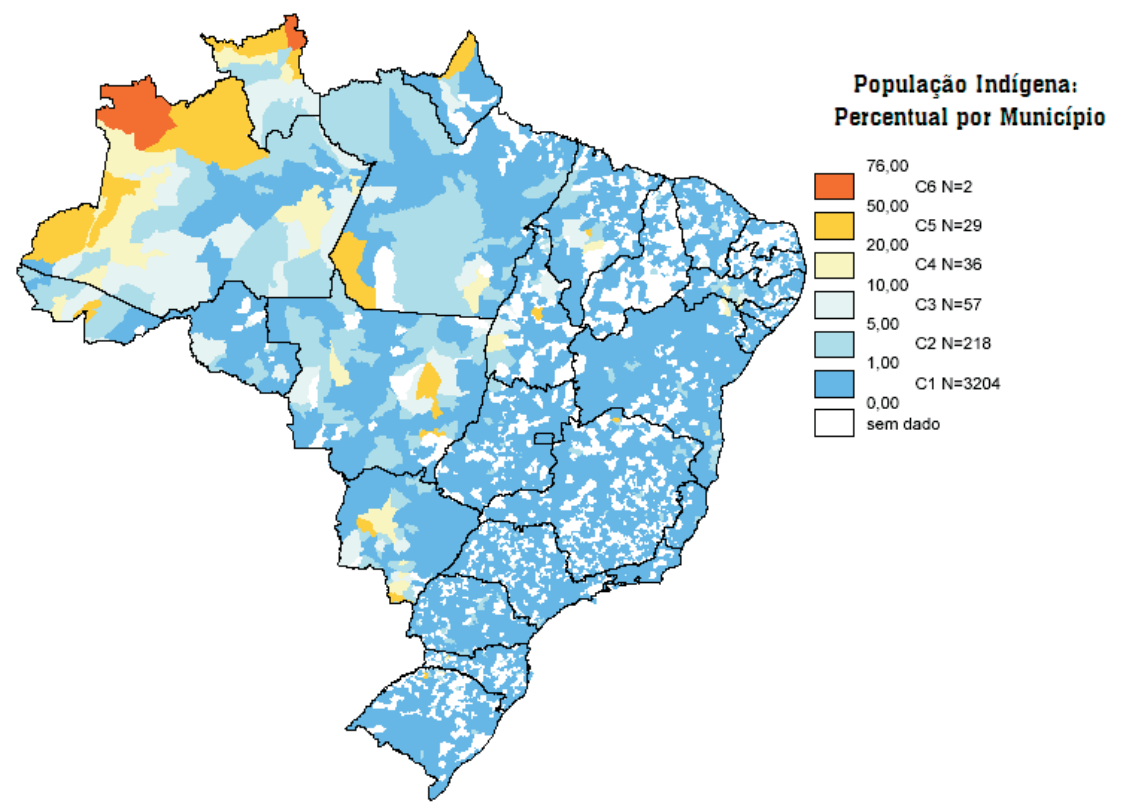

Fonte: IBGE, censo demográfico (2000). 
ferentes regiões do país. Não se trata de um fenômeno que possa ser reduzido a um mapa das terras indígenas e de seus entornos (como aparece no Mapa 1), mas de algo muito mais difuso e complexo, que necessita ser cuidadosamente investigado.

Chama a atenção, logo de início, o elevado número de municípios (3.489) em que essa presença é registrada, afetando 63,3\% dos municípios brasileiros. Ao percorrer essa longa lista, seguindo por estados, é possível identificar sem muita dificuldade aqueles onde se localizam as terras indígenas. Trata-se de uma parte bastante pequena desse universo. Os indígenas representam mais de $20 \%$ da população em $31 \mathrm{mu}-$ nicípios, em outros 36 municípios estão entre $20 \%$ e $10 \%$ da população, em outros 57 estão entre $10 \%$ e $5 \%$.

Vamos deparar um quadro totalmente distinto quando se considera os dados absolutos.

\section{Mapa 3}

Mapa dos Municípios Brasileiros por Faixas Numéricas de Presença Indígena

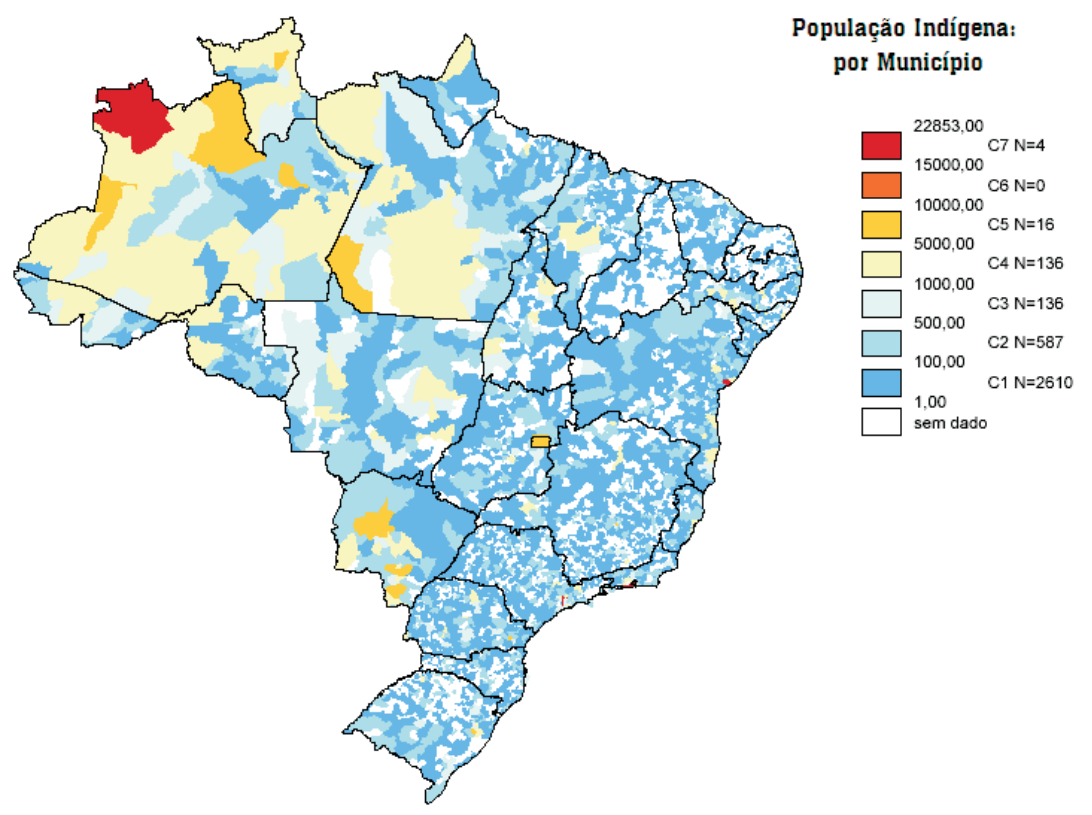

Fonte: IBGE, censo demográfico (2000). 
Em 2.610 municípios há registro da presença de menos de 100 indígenas, em outros 587 essa presença é entre 100 e 500, em outros 272 essa população fica entre 500 e 5 mil declarantes. Ao examinar a lista de municípios dessa última faixa obtém-se uma extensa lista das pequenas e médias cidades do interior do país. Uma parte destas é efetivamente próxima das terras indígenas (embora situadas fora delas), como que indicando uma função de satelização que núcleos urbanos desempenham em relação a áreas rurais circunvizinhas. Uma outra parte apenas se localiza na mesma microrregião (ou mesmo em microrregiões vizinhas), que não implicam relações sociais e espaciais diretas com as terras indígenas, mas que configuram como que vasta e difusa poeira de indicações identitárias fragmentárias e heterogêneas, cuja unidade é remeter a uma ancestralidade indígena.

A condição urbana torna-se mais clara na faixa imediatamente seguinte, a dos 16 municípios que possuem mais de 5 mil indígenas. Embora alguns poucos desses municípios possuam terras indígenas ${ }^{23}$, trata-se, na maioria, de capitais $^{24}$, para os quais os indígenas se deslocam em busca de melhores condições socioeconômicas. Na faixa seguinte, dos municípios (quatro) que concentram maior população indígena, apenas São Gabriel da Cachoeira Amazonas, tem a sede municipal cercada por terras indígenas, os demais (São Paulo, Salvador e Rio de Janeiro), constituem-se em foco de atração para os migrantes rurais (entre os quais estão os indígenas).

O que surge como resultado desse trabalho do IBGE é uma primeira aproximação ao que seria atualmente o equivalente social e identitário do caboclo nos censos de 1872 e 1890, ou do índio colonial nos textos historiográficos. Não é por acaso que alguns estados que possuíam expressivo contingente de indígenas naqueles censos, como Bahia, São Paulo, Minas Gerais, Pernambuco, Paraná e Rio Grande do Sul, registram hoje em dia uma presença indígena igualmente significativa, expressa em um número relativamente elevado de indígenas distribuídos por um grande número de municípios.

Nesse sentido, o censo enquanto instrumento cognitivo que permitiria apreender a manutenção de componentes identitários em uma população indígena dispersa e desterritorializada, estaria apontando para um fenômeno que está apenas começando a ser estudado pelos cientistas sociais, historiadores e demógrafos ${ }^{25}$. Trata-se da persistente, difusa e generalizada presença indígena na formação do Brasil, de forma algu- 
ma circunscrita ao século XVI, mas estendida ao longo de cinco séculos (ver Pacheco de Oliveira, 2010). Seria equivocado também buscar essa importância apenas no passado, pois este é um país em que as terras indígenas hoje reconhecidas representam quase 15\% de seu território.

A dinâmica econômica e política desta colônia na América portuguesa, de uma nação que se estrutura enquanto um Império e só inicia a sua transformação em República nos últimos anos do século XIX, não pode ser entendida omitindo-se o fator que permitiu tal continuidade histórica. Ou seja, a permanente criação de fronteiras interiores (ver Pacheco de Oliveira, 2008 e 2010), do exercício de um colonialismo interno, em que a população nativa, as terras que habitavam e os recursos que possuíam, foram continuamente decretadas como espaços econômicos a serem incorporados mediante uma variada gama de expedientes (muitas vezes legalizados) que incluíam o terror e a guerra, a escravidão disfarçada, os deslocamentos compulsórios e a imposição da tutela.

É este pano de fundo histórico, ainda pouco investigado, mas que alimenta o imaginário, as instituições e práticas brasileiras, que uma leitura sociológica do censo 2000 espelha com inusitada força. Um aspecto que esteve frequentemente recalcado nas mais importantes interpretações do Brasil, e que foi tratado apenas em sua dimensão insulada e etnificada pelos etnólogos, vem agora à luz. Trata-se de apontar a continuidade de vínculos identitários supostamente soterrados pela história política oficial e refratados pela consciência europeizada da elite intelectual ${ }^{26}$.

Agora em um contexto histórico bastante novo, no pós-Constituição Federal de 1988 (ver Pacheco de Oliveira, 2008), em um mundo globalizado em que as políticas públicas estão marcadas pelo multiculturalismo, revalorizando as identidades étnicas e locais, as mobilizações indígenas voltam a ocupar um espaço cada vez maior na agenda política e desvelam a importância do componente indígena na formação da nacionalidade e nas perspectivas futuras de desenvolvimento.

(Recebido para publicação abril de 2012) (Aprovado para publicação em agosto de 2012) 


\section{NOTAS}

1. Cabe notar que, em português, atos tão distintos como aplicar uma ordem numérica e relatar uma história são comumente referidos através do mesmo verbo ("contar").

2. Existem, assim, alguns autores que consideram que dados demográficos sobre povos indígenas, por não operarem com as unidades étnicas ou culturais que os dividem, não teriam qualquer utilidade para uma análise antropológica (Silva, 1994).

3. Uma importante aplicação dessa orientação no domínio da história cultural foi realizada por Darnton (1986), abordando tanto fontes escritas (crônicas de costumes e relatórios administrativos), quanto orais (os contos populares dos camponeses franceses). Para um uso no Brasil relativo a fontes bibliográficas e arquivísticas sobre os povos indígenas ver Fernandes (1954) e Pacheco de Oliveira (1987b, 1988).

4. É interessante atentar para o fato de que os dados quantitativos, por sua aparência de exatidão e objetividade, tendem a favorecer a crença no seu automatismo, favorecendo a que as operações de comparação e normatização tornem-se ainda mais invisíveis e compulsivas.

5. Em uma leitura cuidadosa dos relatos hispânicos do século XVI sobre os indígenas das Américas do Norte e Central, Todorov (1983) mostra a diversidade de interpretações e doutrinas entre esses autores, sublinhando a heterogeneidade dos relatos e das propostas quanto ao papel que o indígena deveria assumir na colonização da região. Para uma interpretação mais referida ao Brasil e à América do Sul, ver Buarque de Holanda (1969).

6. Categoria utilizada pela historiadora Karen Spalding no contexto da América hispânica para designar os indígenas que aceitaram o batismo e passaram a viver sob a autoridade colonial em cidades ou povoações do interior. Estudos recentes sobre história indígena no Brasil revelam que esses índios mantiveram uma identidade e um comportamento diferenciado dentro da sociedade colonial (Monteiro, 1994; Almeida, 2003), devendo ser analisados com mais rigor e profundidade, ao invés de serem equiparados ao conjunto da população.

7. Cabe notar, no entanto, que no português falado no Brasil caboclo tem um sentido mais ambíguo e encoberto, apenas insinuando uma ascendência indígena (mas que poderia corresponder também a um uso metafórico, aplicado a um habitante do interior, de costumes simples e rudimentares). A identificação do caboclo como indígena foi, assim, sobretudo residual e negativa (isto é, por tratar-se de população livre, que se distinguia tanto da condição de brancos quanto da de negros, bem como dos estrangeiros).

8. A própria Lei de Terras, de 1850, estabelecia que as posses indígenas resultantes de antigos aldeamentos deveriam ser ratificadas por ato administrativo (demarcação), caso contrário seriam julgadas de aldeamentos abandonados ou extintos, devendo ser colocadas à venda em leilão público.

9. As tentativas de suprir essa lacuna por meio do exame criterioso da distribuição dos pardos pode talvez produzir alguns dados relativamente confiáveis somente em casos extremos, como o do Amazonas, em que o contingente de negros e seus descendentes mestiços é bastante inferior ao de indígenas e seus descendentes. Na maioria das situações, mesmo procedendo a um trabalho de peneiramento dos dados por es- 


\section{João Pacheco de Oliveira}

tados e municípios, apoiados em séries históricas e notícias sobre fluxos migratórios, trata-se de um exercício arriscado e com resultados absolutamente incertos.

10. Vide as análises de Cardoso de Oliveira (1972) e Pacheco de Oliveira (1999a).

11. Para uma análise mais aprofundada do SPI e da figura de Rondon ver Lima (1994).

12. Segundo os dados coletados no censo de 1940 , falavam outra língua dentro de casa $25 \%$ dos residentes em Santa Catarina e 22,5\% no Rio Grande do Sul. No censo de 1950 esses números sofrem uma expressiva diminuição.

13. A crítica dessa ideologia - conhecida como "rondonismo", "indigenismo" ou "sertanismo" - está realizada em seus múltiplos aspectos em dois livros (Pacheco de Oliveira, 1998 e 2006) e foi retomada recentemente em sua dimensão histórica enquanto parte de um processo de nation building (Pacheco de Oliveira, 2004, 2009 e 2011).

14. Ver, em especial, os trabalhos de Lima (1994).

15. Ver, a esse respeito, a tese de Carlos Augusto da Rocha Freire (2005).

16. PETI é uma abreviatura utilizada para o Projeto Estudo sobre Terras Indígenas: Invasões, uso do solo e outras ocupações sobrepostas, sediado no Museu Nacional/UFRJ, sob a coordenação de João Pacheco de Oliveira, que atuou de 1986 a 1993 no monitoramento das terras indígenas, contando com o apoio da Fundação Ford. Tal projeto, formatado a partir de reflexões anteriores (Pacheco de Oliveira, 1983), resultou em uma extensa produção, com dois livros (Pacheco de Oliveira, 1998 e 2006), além de muitos artigos, dos quais cabe destacar alguns (Pacheco de Oliveira, 1987, 1994, 1997 e 1999b) mais diretamente relacionados ao tema deste artigo.

17. Organização Não Governamental que, desde o final dos anos 1970, atou na divulgação de informações sobre os povos indígenas, apoiando os seus processos de mobilização por direitos. Nos anos 90 veio a dar origem ao atual Instituto Socioambiental (ISA).

18. Vide, entre outros, Ricardo (1994).

19. Uma análise mais cuidadosa deste contexto pode ser encontrada em Pacheco de Oliveira e Piedrafita Iglésias (2002).

20. Na apresentação do censo de 1940 é observado que as pessoas entrevistadas foram classificadas enquanto brancos, negros e amarelos, sendo usado um traço para indicar a inadequação a essa categoria.

21. O qual na realidade vinha a integrar-se em um projeto analítico maior, de descrição do processo de assimilação das minorias nas Américas (vide Wagley e Harris, 1967).

22. Vide, entre outros, Costa (1974), Harris (1974), Skidmore (1974), Degler (1976), Hasenbalg (1979), Silva e Hasenbalg (1993).

23. Como Tabatinga, e São Paulo de Olivença, municípios da microrregião do Alto Solimões / AM, respectivamente com 7.255 e 6.634 habitantes indígenas, isto para exemplificar concretamente um fenômeno que se encontra em outras regiões do país.

24. Como Manaus, com 7.894, e Boa Vista, com 6.150, entre outras capitais.

25. Cabe destacar os estudos e análises desenvolvidos, com a coordenação de Nilza Pereira, pelo próprio IBGE (vide IBGE, 2005 e 2012) e por outros pesquisadores (entre estes, Paoliello, 2008 e 2012). Um polo agregador de reflexões sobre esta temática tem sido o GT-Demografia dos Povos Indígenas, da ABEP/Associação Brasileira de Estudos Populacionais.

26. Vide Pacheco de Oliveira e Rocha Freire (2007); Pacheco de Oliveira (2008 e 2010). 


\section{REFERÊNCIAS BIBLIOGRÁFICAS}

ALMEIDA, Maria Regina Celestino de. (2003), Metamorfoses Indígenas: Identidade e Cultura nas Aldeias Coloniais do Rio de Janeiro. Rio de Janeiro, Arquivo Nacional.

ANDRADA E SILVA, José Bonifácio de. (1992), “Apontamentos para a Civilização dos Índios Bravos do Império do Brasil (1823)”, in M. Carneiro da Cunha (org.), Legislação Indigenista no Século XIX. São Paulo, Edusp, pp. 347-360.

BUARQUE DE HOLANDA, Sérgio. (1969), Visões do Paraíso. Rio de Janeiro, Livraria José Olympio Editora.

CARDOSO DE OLIVEIRA, Roberto. (1972), "Problemas e Hipóteses Relativos à Fricção Interétnica", in A Sociologia do Brasil Indígena. Brasília, Editora da Universidade de Brasília, pp. 85-129.

CARNEIRO, Carlos. (1922), "População". Diccionário Histórico, Geographico e Ethnographico Brasileiro. Rio de Janeiro, Imprensa Nacional, vol. 1, pp. 239-248.

CONSELHO INDIGENISTA MISSIONÁRIO (CIMI). (1982), “Levantamento da Realidade Indígena". Porantim, vol. 37, pp. 8-12.

COSTA, Tereza Cristina de Araújo. (1974), “O Princípio Classificatório 'Cor', sua Complexidade e Implicações para um Estudo Censitário". Revista Brasileira de Geografia, vol. 36, no 3, pp. 91-103.

DANIEL, João (SJ). (1976), “O Tesouro Descoberto no Rio Amazonas”. Anais da Biblioteca Nacional, vol. 95, tomos 1-2, separata.

DARNTON, Robert. (1986), O Grande Massacre dos Gatos e outros Episódios da História Cultural Francesa. Rio de Janeiro, Graal.

DEGLER, Carl N. (1976), Nem Preto nem Branco: Escravidão e Relações Raciais no Brasil e nos Estados Unidos. Rio de Janeiro, Editorial Labor.

FERNANDES, Florestan. (1967), A Investigação Etnológica no Brasil e outros Ensaios. São Paulo, Livraria Pioneira.

FOUCAULT, Michel. (1977), Microfísica do Poder. Rio de Janeiro, Graal.

FREYRE, Gilberto (1933), Casa-Grande E senzala: Formação da Família Brasileira sob o Regime de Economia Patriarcal. Rio de Janeiro, Livraria José Olympio.

FUNDAÇÃO NACIONAL DO ÍNDIO (Funai). (1981), A Verdade sobre o Índio Brasileiro. Brasília, Funai.

GARCIA, Rodolfo. (1922), “Ethnographia Indígena”. Diccionario Histórico, Geographico e Ethnographico Brasileiro. Rio de Janeiro, Imprensa Nacional, vol. 1, pp. 249-277.

GALVÃO, Eduardo. (1979), “Áreas Culturais no Brasil”, in E. Galvão, Encontro de Sociedades. Rio de Janeiro, Paz e Terra.

GLAZER, Nathan e MOYNIHAN, Daniel P. (1963), Beyond the Melting-pot. Cambridge, Harvard University Press.

HASENBALG, Carlos. (1979), Discriminação e Desigualdades Raciais no Brasil. Rio de Janeiro, Graal. 


\section{João Pacheco de Oliveira}

HARRIS, Marvin. (1970), "Referential Ambiguity in the Calculus of Brazilian Racial Identity". Southwestern Journal of Anthropology, vol. 26, no 1.

INSTITUTO BRASILEIRO DE GEOGRAFIA E ESTATÍSTICA (IBGE). (1940), Censo de 1940. Rio de Janeiro, IBGE.

. (1950), Censo de 1950. Rio de Janeiro, IBGE.

. (2005), Tendências Demográficas. Uma Análise dos Indígenas com Base nos Resultados da Amostra nos Censos Demográficos de 1991 e 2000. Organização de Nilza Pereira. Estudos e Pesquisas, 16. Rio de Janeiro, IBGE.

(2012), Censo Demográfico 2010. Características Gerais dos Indígenas. Resultados do Universo. Rio de Janeiro, IBGE.

LIMA, Antonio Carlos de Souza. (1994), Um Grande Cerco de Paz. Petrópolis/São Paulo, Vozes/ANPOCS.

MONTEIRO, John. (1994), Negros da Terra: Índios e Bandeirantes nas Origens de São Paulo. São Paulo, Companhia das Letras.

PACHECO DE OLIVEIRA, João. (1983), “Terras Indígenas no Brasil: Uma Abordagem Sociológica". América Indígena, vol. XLIII, no 3, pp. 655-682.

. (1987a), “Terras Indígenas: Uma Avaliação Preliminar de seu Reconhecimento Oficial e de Outras Destinações Propostas", in Terras Indígenas no Brasil. São Paulo, CEDI, pp. 7-32.

. (1987b), "Elementos para uma Sociologia dos Viajantes", in J. Pacheco de Oliveira (org.), Sociedades Indígenas e Indigenismo no Brasil. São Paulo/Rio de Janeiro, Ed. Marco Zero/UFRJ, pp. 84-148.

. (1988), "Os Atalhos da Magia". Reflexões sobre os Relatos dos Naturalistas Viajantes e a Etnografia Indígena". Boletim do Museu Paraense Emílio Goeldi. Série Antropologia, vol. 3, no 2, pp. 155-188.

. (1994), “Las Estadísticas sobre Tierras Indígenas en Brasil: Una Evaluación Crítica". Estudios Sociodemograficos de Pueblos Indígenas. Santiago de Chile, CELADE, pp. 523-537.

(1997), “Pardos, Mestiços ou Caboclos? Os Índios nos Censos Nacionais". Horizontes Antropológicos, no 6, outubro, pp. 60-83.

(org.). (1998), Indigenismo e Territorialização: Poderes, Rotinas e Saberes Coloniais no Brasil Contemporâneo. Rio de Janeiro, Contra Capa.

. (1999a), Ensaios em Antropologia Histórica. Rio de Janeiro, Editora da UFRJ.

. (1999b), "Entering and Leaving the 'Melting-pot': A History of Brazilian Indians in the National Censuses". Journal of Latin American Anthropology, vol. 4, no 2, pp. 190-211.

PACHECO DE OLIVEIRA, João e PIEDRAFITA IGLESIAS, Marcelo Manuel. (2002), “Direitos e Cidadania na Reconstrução dos Territórios Indígenas no Brasil", in Pueblos Indígenas de América Latina: Retos para um Nuevo Milênio. Lima, Ford Foundation/OXFAM America. DVD.

PACHECO DE OLIVEIRA, João. (2004), “Uma Etnologia dos 'Índios Misturados'? Situação Colonial, Territorialização e Fluxos Culturais", in J. Pacheco de Oliveira (org.), A 


\section{Mensurando Alteridades, Estabelecendo Direitos: Práticas e Saberes...}

Viagem da Volta: Etnicidade, Política e Reelaboração Cultural no Nordeste Indígena. (2a ed.). Rio de Janeiro, Contra Capa, pp. 13-42.

(org.). (2006), Hacia una Antropología del Indigenismo: Estudios Críticos sobre los Procesos de Dominación y las Perspectivas Políticas Actuales de los Indígenas en Brasil. Lima/Rio de Janeiro, CAAP/Contra Capa.

PACHECO DE OLIVEIRA, João e ROCHA FREIRE, Carlos Augusto. (2007), A Presença Indígena na Formação do Brasil. Brasília, MEC/SECADI.

PACHECO DE OLIVEIRA, João. (2008), "Sem a Tutela, uma Nova Moldura de Nação", in R. G. Oliven, M. Ridenti e G. M. Brandão (orgs.), A Constituição de 1988 na Vida Brasileira. São Paulo, Anpocs, pp. 251-275.

(2010), "O Nascimento do Brasil: Revisão de um Paradigma Historiográfico". Anuário Antropológico 2009, julho, pp. 11-39.

(2011), "Trama Histórica e Mobilizações Políticas Atuais", in J. Pacheco de Oliveira (org.), A Presença Indígena no Nordeste: Formas de Territorialização, Modos de Reconhecimento e Regimes de Memória. Rio de Janeiro, Contra Capa, pp. 633-687.

PAOLIELLO, Tomas. (2008), "O Crescimento da Presença Indígena nos Censos Nacionais: A Região Nordeste", in Anais do XVI Encontro Nacional de Estudos Populacionais: As Desigualdades Sócio-demográficas e os Direitos Humanos no Brasil. Caxambu, ABEP. Disponível em http://www.abep.nepo.unicamp.br/encontro2008/docsPDF/ ABEP2008ã1503.pdf.

(2012), Revitalização Étnica e Dinâmica Territorial. Rio de Janeiro, Contra Capa.

RIBEIRO, Darcy. (1970), Os Índios e a Civilização. (2a ed.). Petrópolis, Vozes.

RICARDO, Carlos Alberto. (1995), “Os Índios e a Sociodiversidade Nativa Contemporânea no Brasil", in A. Lopes da Silva, A. e L. D. Grupioni (orgs.), A Temática Indígena na Escola. Brasília, MEC/UNESCO/MARI.

ROCHA FREIRE, Carlos Augusto da. (2005), Sagas Sertanistas. Tese de doutorado em Antropologia Social, Rio de Janeiro, PPGAS/Museu Nacional/UFRJ.

SILVA, Márcio Ferreira da. (1994), "A Demografia e os Povos Indígenas no Brasil". Revista Brasileira de Estudos de População, vol. 11, no 2, pp. 261-264.

SILVA, Nelson do Valle e HASENBALG, Carlos. (1993), Relações Raciais no Brasil Contemporâneo. Rio de Janeiro, Rio Fundo Editora.

SKIDMORE, Thomas E. (1974), Blacks into White: Race and Nationality in Brazilian Thougth. New York, Oxford University Press.

SOUZA E SILVA, Joaquim Norberto. (1951), Investigações sobre os Recenseamentos da População Geral do Império. Rio de Janeiro, IBGE.

TODOROV, Tzvetan. (1983), A Conquista da América: A Questão do Outro. São Paulo, Martins Fontes.

WAGLEY, Charles e HARRIS, Marvin (eds.). (1967), Minorities in the New World: Six Case Studies. New York, Columbia University Press. 


\section{ABSTRACT \\ Measuring Forms of Otherness and Establishing Rights: Government Practices and Knowledge in the Creation of Ethnic Frontiers}

This article has two objectives, focusing on the statistics for Brazil's indigenous population. One objective is methodological, starting with a critical and ethnographic perspective to analyze the quantitative data as both cognitive and political tools related to the recognition of rights, which need to be framed within the colonization and state-building processes. The second, focusing on current and past discrepancies between data from indigenous affairs authorities and the national censuses, as currently represented by the National Indian Foundation (Funai) and the Brazilian Institute of Geography and Statistics (IBGE), respectively, reflects on the heuristic potential of the latter, thereby allowing visualization of the extent and importance of the indigenous presence in the country's formation, counter to the administrative ethnicization and neglect in official history.

Key words: national censuses; indigenous peoples in Brazil; anthropology of numerical records

\section{RÉSUMÉ}

Mesurer des Altérités, Établir des Droits: Pratiques et Savoirs Gouvernementaux dans la Création de Frontières Ethniques

Prenant pour objet les données numériques et statistiques produites sur la population indigène du Brésil, cet article a deux objectifs. L'un d'eux, de nature méthodologique, part d'une perspective critique et ethnographique et a pour but d'analyser les données quantitatives en tant qu'outils à la fois cognitifs et politiques dans le sens où ils sont reliés à des processus de connaissance de droits devant être contextualisés en fonction des processus de colonisation et de state building. Le deuxième se concentre sur la divergence (actuelle et passée) entre les données fournies par la Fondation Nationale de l'Indien (Funai) qui se consacre à la question indigène et les recensements nationaux réalisés par 1’Institut Brésilien de Géographie et Statistique (IBGE). Il donne lieu à une réflexion sur le potentiel heuristique de ces derniers, dans la mesure où ils permettent de visualiser l'extension et l'importance de la présence indigène dans la formation nationale, en dépit du contre-courant d'ethnification administrative et du mépris de l’histoire officielle.

Mots-clés: recensements nationaux; peuples indigènes du Brésil; anthropologie des registres numériques 